\title{
Perspectives Concerning the Influence of Protein Intake for Renal Function in Diabetic Nephropathy
}

\author{
Yoshinobu Kato ${ }^{1}$, Yoshikane Kato ${ }^{1}$, Hiroshi Bando ${ }^{1,2^{*}}$ \\ ${ }^{1}$ Kanaiso Hospital, Komatsushima, Tokushima, Japan \\ ${ }^{2}$ Medical Research / Tokushima University, Tokushima, Japan \\ Corresponding Author: Hiroshi BANDO, MD, PhD, FACP ${ }^{\text {ORCID iD }}$ \\ Address: Tokushima University /Medical Research, Nakashowa 1-61, Tokushima 770-0943, Japan. \\ Received date: 06 January 2021; Accepted date: 08 February 2021; Published date: 15 February 2021
}

Citation: Kato Y, Kato Y, Bando H. Perspectives Concerning the Influence of Protein Intake for Renal Function in Diabetic Nephropathy. Diab Res Open Access. 2021 Feb 15;3(1):7-10.

Copyright (c) 2021 Kato Y, Kato Y, Bando H. This is an open-access article distributed under the Creative Commons Attribution License, which permits unrestricted use, distribution, and reproduction in any medium, provided the original work is properly cited.

\begin{abstract}
Regarding the diet treatment of diabetic nephropathy, protein restriction has been recommended. American Diabetes Association (ADA) proposed protein restriction guidelines in the 2008 edition. However, this comment was deleted in the 2013/2019 edition, because of insufficient evidence. A recent report showed that the intake of plant protein has a protective effect on the decrease of estimated glomerular filtration rate (eGFR), and the intake of animal protein has neither protection nor deterioration. There are controversies about the relationship between protein intake and the reduction of renal function. Further research will be expected for diabetic nephropathy, diabetic kidney disease (DKD), and chronic kidney disease (CKD).
\end{abstract}

\section{Keywords}

Diabetic Nephropathy, American Diabetes Association (ADA), Estimated Glomerular Filtration Rate (eGFR), Diabetic Kidney Disease (DKD), Chronic Kidney Disease (CKD)

\author{
Abbreviations \\ American Diabetes Association (ADA); Estimated Glomerular Filtration Rate (eGFR); Diabetic Kidney Disease
} (DKD); Chronic Kidney Disease (CKD)

In recent years, diabetes, diabetic nephropathy, diabetic kidney disease (DKD), chronic kidney disease (CKD), and atherosclerotic cardiovascular disease (ASCVD) have been prevalent worldwide [1]. Among them, a protein-restricted diet has been often used for patients with impaired renal function. It was thought to be that as protein intake increases, renal function declines. There are controversies concerning this policy [2]. The authors have continued medical practice and research for patients with diabetes [3], CKD, dialysis [4], and ASCVD [5], associated with a low carbohydrate diet (LCD) [6].

From a historical point of view, American Diabetes Association (ADA) actually made recommendations on an adequate diet. Among them, the description of protein restriction for patients with kidney disease began in the 1987 edition [7]. After that, in the 2008 edition, there was a description of protein restriction of 0.8 to $1.0 \mathrm{~g} / \mathrm{kg} /$ day for early nephropathy and 0.8 $\mathrm{g} / \mathrm{kg} /$ day for late nephropathy [8]. Thus, it is true that there has been a recommendation of a long 
history for protein restriction.

However, since the 2013 edition, the content of comments has changed due to various evidences. In other words, it has changed to the situation where the clinical significance of protein restriction has been denied [9]. This trend has been carried over in the 2019 edition as well [10]. There is some reason for these changes, in which they are decided by recommendation or evidence. The guideline was previously a consensus based on a draft recommendation, agreed by experts for diabetes. However, the management was changed by the comments from the International Network of Guidelines [11]. By complying with this, medical content with no scientific basis or not sufficient evidence has been excluded from the consensus. Therefore, the clinical significance of protein restriction has not been included.

On the other hand, a protein-restricted diet has been rather recommended for the protection of renal function from before to the present. In this regard, the Japan Diabetes Association (JDA) showed the comment that protein restriction may be effective in suppressing the progression of diabetic nephropathy after the overt nephropathy stage, but clinical evidence is insufficient. In detail, there is not enough scientific evidence for the possibility that protein intake may worsen renal function and that a protein-restricted diet may protect renal function.

Under these circumstances, a new report has been released. It was a cohort study of Australian women with the results that protein intake was involved in the protection of renal function. This revealed the opposite perspective of the relationship between protein intake and renal function [12]. This report is a subgroup analysis of a randomized controlled trial (RCT) called the Calcium Intake Fracture Outcome Study. They used 1,460 randomly selected cases from 5,586 cases [13]. For dietary information, the Dietary Questionnaire for Epidemiology Studies version 2 was used to digitize eating habits for the past 12 months. For nutritional analysis, the AUStralian Food and NUTrient Database (AUSNUT 2011-13) was used to determine protein intake in $0,5,10$ years. In the clinical examination, a large number of biomarkers were analyzed, and the estimated glomerular filtration rate (eGFR) for $0,5,10$ years was calculated from blood creatinine and cystatin C [14].

As a result, the average protein intake/day was 75.2 $\mathrm{g}$ in total, $51.4 \mathrm{~g}$ in animals, and $28.9 \mathrm{~g}$ in plants [12]. Total data showed that eGFR decreased at a rate of $0.64 \mathrm{~mL} / \mathrm{min} / 1.73 \mathrm{~m}^{2}$ per year. Increasing plant protein intake by $10 \mathrm{~g} /$ day slowed the decline in eGFR by 0.13 $\mathrm{mL} / \mathrm{min} / 1.73 \mathrm{~m}^{2}$ per year. This was not affected by the presence or absence of diabetes and hypertension. On the other hand, in the case of animal protein intake, the rate of decrease did not change regardless of rough calculation or adjustment calculation [12].

The characteristic of this result is that the intake of plant protein has a protective effect on the decrease of eGFR, and the intake of animal protein has neither protection nor deterioration. Similar results were found in the previous reports of the patients with type 2 diabetes [15] and non-diabetes [16]. Some reports revealed the opposite results. In the US cohort study Nurses' Health Study, protein intake and the rate of eGFR decline were positively correlated when eGFR was $<80 \mathrm{~mL} / \mathrm{min} / 1.73 \mathrm{~m}^{2}$ [17]. In a Dutch study, protein intake was positively associated with the rate of eGFR decline in both plant and animal protein intake in patients with post-myocardial infarction [18]. From various data mentioned above, the following points are suggested: i) there is some hypothesis that protein intake reduces renal function, ii) however, there is a way to increase plant protein rather than animal protein, iii) a patient-centered approach will be recommended that presents treatment options to patients in the future.

There is a recent report examining the presence or absence of proteinuria and eGFR [19]. The decrease rate in eGFR was studied in diabetic patients with eGFR $<60 \mathrm{~mL} / \mathrm{min} / 1.73 \mathrm{~m}^{2}$. When the nephropathy was during the microalbuminuria period, it was about $2.0 \mathrm{~mL} / \mathrm{min} / 1.73 \mathrm{~m}^{2}$ per year. In the case of overt proteinuria, it was $3.0 \mathrm{~mL} / \mathrm{min} / 1.73 \mathrm{~m}^{2}$ per year [19]. If eGFR decreases at a rate greater than 5.0 $\mathrm{mL} / \mathrm{min} / 1.73 \mathrm{~m}^{2}$ per year, it should be diagnosed as rapid progression and treated as a special diabetic case 
$[20,21]$. On the other hand, an RCT study revealed that there is no relationship between protein intake (compliance with a protein-restricted diet) and changes in eGFR and creatinine clearance (Ccr) [22].

As described above, it seems difficult to draw certain conclusions from many reports. When actually diagnosing patients with $\mathrm{CKD}$, hypertension, and diabetes in clinical settings, it will be necessary for each patient to understand the stage and manage it adequately. The authors have continued to develop LCD, in which protein restriction in nephropathy has been an important issue. A study for LCD was reported, where 200 T2DM patients showed eGFR values at $0,1,2$, and 3 years for $74.4,73.6,73.1,72.1$ $\mathrm{mL} / \mathrm{min} / 1.73 \mathrm{~m}^{2}$, a decrease of $0.7 \mathrm{~mL} / \mathrm{min} / 1.73 \mathrm{~m}^{2}$ per year [23]. To date, there have been no papers with evidence of a clear decrease in eGFR due to LCD, and authors will carefully observe the further development of research in the future.

\section{References}

[1] Hassan NK, Gillani SW, Kaoje AA, Fari FM, Elashmouny HM, Sulayman NM, Mohammadi NA. A Clinical Review on Nutritional Requirements and Assessment for Type 2 Diabetes Mellitus with Chronic Renal Disease. Curr Diabetes Rev. 2020;16(9):922-30. [PMID: 32072916]

[2] Joshi S, McMacken M, Kalantar-Zadeh K. PlantBased Diets for Kidney Disease: A Guide for Clinicians. Am J Kidney Dis. 2021 Feb;77(2):287-96. [PMID: 33075387]

[3] Kato Y, Bando H, Yamashita H, Yada S, Tokuhara

S, Tokuhara H, Mutsuda T. Seasonal changes in HbA1c values from young to elderly diabetic patients. J Diabetes Metab Disord Control. 2019 Aug 30;6(3):8992.

[4] Kakutani H, Kato Y, Fujikawa T, Kawata T, Yamamoto M, Wada K, Ishikura K, Shirai Y, Narutaki M, Kanazawa S, Matsuzaki S. Carnitine for body composition in hemodialysis patients. Edel J Biomed Res Rev. 2020 Feb 27;2(1):5-8.

[5] Kato Y, Bando H, Matsuzaki S, Waka S. Current topics of possible pharmacotherapy for chronic kidney disease (CKD) and diabetes. Pharm Pharmacol Int J. 2020 Apr 15;8(2):87-89.

[6] Bando H. Useful tips for actual low carbohydrate diet (LCD) with super-, standard-and petit-LCD methods. EC Nutrition. 2020 Apr 8;15(5):1-4.

[7] Nutritional recommendations and principles for individuals with diabetes mellitus: 1986. American Diabetes Association. Diabetes Care. 1987 JanFeb;10(1):126-32. [PMID: 3032536]

[8] American Diabetes Association, Bantle JP, WylieRosett J, Albright AL, Apovian CM, Clark NG, Franz MJ, Hoogwerf BJ, Lichtenstein AH, Mayer-Davis E, Mooradian AD, Wheeler ML. Nutrition recommendations and interventions for diabetes: a position statement of the American Diabetes Association. Diabetes Care. 2008 Jan;31 Suppl 1:S61-78. Erratum in: Diabetes Care. 2010 Aug;33(8):1911. [PMID: 18165339]

[9] Evert AB, Boucher JL, Cypress M, Dunbar SA, Franz MJ, Mayer-Davis EJ, Neumiller JJ, Nwankwo R, Verdi CL, Urbanski P, Yancy WS Jr. Nutrition therapy recommendations for the management of adults with diabetes. Diabetes Care. 2014 Jan;37 Suppl 1:S120-43. [PMID: 24357208]

[10] Evert AB, Dennison M, Gardner CD, Garvey WT, Lau KHK, MacLeod J, Mitri J, Pereira RF, Rawlings K, Robinson S, Saslow L, Uelmen S, Urbanski PB, Yancy WS Jr. Nutrition Therapy for Adults With Diabetes or Prediabetes: A Consensus Report. Diabetes Care. 2019 May;42(5):731-54. [PMID: 31000505]

[11] Qaseem A, Forland F, Macbeth F, Ollenschläger G, Phillips S, van der Wees P; Board of Trustees of the Guidelines International Network. Guidelines International Network: toward international standards for clinical practice guidelines. Ann Intern Med. 2012 Apr 3;156(7):525-31. [PMID: 22473437]

[12] Bernier-Jean A, Prince RL, Lewis JR, Craig JC, Hodgson JM, Lim WH, Teixeira-Pinto A, Wong G. Dietary plant and animal protein intake and decline in estimated glomerular filtration rate among elderly women: a 10-year longitudinal cohort study. Nephrol Dial Transplant. 2020 May 26:gfaao81. [PMID: 32457981]

[13] Prince RL, Devine A, Dhaliwal SS, Dick IM. Effects of calcium supplementation on clinical fracture and bone structure: results of a 5-year, double-blind, placebo-controlled trial in elderly women. Arch Intern Med. 2006 Apr 24;166(8):869-75. [PMID: 16636212] [14] Inker LA, Schmid CH, Tighiouart H, Eckfeldt JH, Feldman HI, Greene T, Kusek JW, Manzi J, Van Lente F, 
Citation: Kato Y, Kato Y, Bando H. Perspectives Concerning the Influence of Protein Intake for Renal Function in Diabetic Nephropathy. Diab Res Open Access. 2021 Feb 15;3(1):7-10.

Commentary

Zhang YL, Coresh J, Levey AS; CKD-EPI Investigators. Estimating glomerular filtration rate from serum creatinine and cystatin C. N Engl J Med. 2012 Jul 5;367(1):20-29. Erratum in: N Engl J Med. 2012 Aug 16;367(7):681. Erratum in: N Engl J Med. 2012 Nov 22;367(21):206o. [PMID: 22762315]

[15] Oosterwijk MM, Soedamah-Muthu SS, Geleijnse JM, Bakker SJL, Navis G, Binnenmars SH, Gant CM, Laverman GD. High Dietary Intake of Vegetable Protein Is Associated With Lower Prevalence of Renal Function Impairment: Results of the Dutch DIALECT-1 Cohort. Kidney Int Rep. 2019 Feb 21;4(5):710-19. [PMID: 31080926]

[16] Yuzbashian E, Asghari G, Mirmiran P, Hosseini FS, Azizi F. Associations of dietary macronutrients with glomerular filtration rate and kidney dysfunction: Tehran lipid and glucose study. J Nephrol. 2015 Apr;28(2):173-80. [PMID: 24899124]

[17] Knight EL, Stampfer MJ, Hankinson SE, Spiegelman D, Curhan GC. The impact of protein intake on renal function decline in women with normal renal function or mild renal insufficiency. Ann Intern Med. 2003 Mar 18;138(6):46o-67. [PMID: 12639078]

[18] Esmeijer K, Geleijnse JM, de Fijter JW, Kromhout D, Hoogeveen EK. Dietary protein intake and kidney function decline after myocardial infarction: the Alpha Omega Cohort. Nephrol Dial Transplant. 2020 Jan 1;35(1):106-15. [PMID: 30768201]

[19] Vistisen D, Andersen GS, Hulman A, Persson F, Rossing P, Jørgensen ME. Progressive Decline in Estimated Glomerular Filtration Rate in Patients With
Diabetes After Moderate Loss in Kidney Function-Even Without Albuminuria. Diabetes Care. 2019 Oct;42(10):1886-94. [PMID: 31221677]

[20] Inker LA, Astor BC, Fox CH, Isakova T, Lash JP, Peralta CA, Kurella Tamura M, Feldman HI. KDOQI US commentary on the 2012 KDIGO clinical practice guideline for the evaluation and management of CKD. Am J Kidney Dis. 2014 May;63(5):713-35. [PMID: 24647050]

[21] Rughooputh MS, Zeng R, Yao Y. Protein Diet Restriction Slows Chronic Kidney Disease Progression in Non-Diabetic and in Type 1 Diabetic Patients, but Not in Type 2 Diabetic Patients: A Meta-Analysis of Randomized Controlled Trials Using Glomerular Filtration Rate as a Surrogate. PLoS One. 2015 Dec 28;10(12):eo145505. [PMID: 26710078]

[22] Koya D, Haneda M, Inomata S, Suzuki Y, Suzuki D, Makino H, Shikata K, Murakami Y, Tomino Y, Yamada K, Araki SI, Kashiwagi A, Kikkawa R; LowProtein Diet Study Group. Long-term effect of modification of dietary protein intake on the progression of diabetic nephropathy: a randomised controlled trial. Diabetologia. 2009 Oct;52(10):203745. [PMID: 19652945]

[23] Sanada M, Kabe C, Hata H, Uchida J, Inoue G, Tsukamoto Y, Yamada Y, Irie J, Tabata S, Tabata M, Yamada S. Efficacy of a Moderately Low Carbohydrate Diet in a 36-Month Observational Study of Japanese Patients with Type 2 Diabetes. Nutrients. 2018 Apr 24;10(5):528. [PMID: 29695055]

Keywords: Diabetic Nephropathy, American Diabetes Association (ADA), Estimated Glomerular Filtration Rate (eGFR), Diabetic Kidney Disease (DKD), Chronic Kidney Disease (CKD) 